\title{
The History of Gender Inequalities and the History of Female Struggle against Male Subjugation
}

\author{
Saptorshi Das ${ }^{1}$, Dr (Prof) Arindam Modak ${ }^{2}$ \\ ${ }^{1}$ Department of Humanities, Brainware Group of Institutions/West Bengal University of Technology, India) \\ ${ }^{2}$ (Department of Humanities, National Institute of Technology, India)
}

\begin{abstract}
What is feminism? Is it an outburst or outcry against male-perpetrated atrocities on women? Or is it just the right of a woman to live as she wants to live, by her own ethics and values, as far as she causes no harm, physical or emotional, to anybody? Or is feminism just a chronological narrative of the movements and ideologies that define, establish and defend equal political, economic and social rights for women?

Where do the roots of the struggles for women's liberation lie? Who are the ones who are globally known for their fight against the injustice women are subjected to?

This paper traces the roots of gender bias and throws light on the role and status of women down the ages all over the world. At the same time, it also brings to limelight independent women who have always existed in society and who never believed in gender inequality - Sappho, Christine de Pera, Aphra Behn, Olympe de Gorges, Mary Wollstonecraft, Sojourner Truth, to name a few.

Marx and Engels viewed the liberation sought by these women and others as part of the socialist revolution.

From $B C$ to $A D$, the strife for equality continues. But there is still a long way to go, as this paper highlights, before society can claim itself unbiased towards the genders, and women can live a tranquil existence.

Keywords: feminism, women, gender, bias, liberation
\end{abstract}

It is impossible for a man to contemplate

About the various roles that a woman plays

I know that, for most of the men

Women are commodities to use again and again

According to their convenience and impulse

Till the interest in them dulls

But it is high time that women over all space

Be given their rightful position and place.

We women are a conglomerated essence of magic, spirit, and mysticism

Prone to dreams and fantasies but yet rooted in realism

Whose true value is not celebrated by our world or society

Or even women themselves, though not ordained by Almighty

We are each our own person, in peace or in mutiny

We manifest our own fortune, we build our own destiny.

Women have always been nurturing, selfless

Kind beings, and that has been perceived as a weakness

The coming of the New Millennium has awakened

A power within women, so long forsaken

We are recognizing what we are

The real essence of our selves, our power

We are speaking out and living life, not just existing

In pain or relief, sorrow or joy persisting

Within family, relationship, job, or society

Fulfilling our responsibilities, doing our duty.

One supreme truth is emerging loud and clear

Women have strength, imaginations, and no fear

Women have spirituality that renders them calm and peace

And power to change their lives as and when they please

And to live on their own terms and reasons

Come any weather, come any season 
Protect all that they love and hold dear And are passionate about, far or near...... ( Anonymous)

There is this question which has been plaguing me for quite some time now. The front pages of all newspapers around a year back ran the story of a woman who had been picked up from a Kolkata night club by a group of young men, and brutally raped and beaten up, before she was cast off in a darkened alley somewhere. No matter where I went, this was the only piece of news which interested people enough to keep on talking about it, with of course their own views, deductions, and analyses. Good enough, as majority of the people were all for the criminals getting severe penalty for the monstrous atrocity they had inflicted on a 37-year old woman, a mother of two. A woman, subjected to severe physical torture and mental trauma, deserved the support and emotional encouragement for the attainment of justice. And doggedly determined and resolute in this pursuit of justice for a wrongly treated woman was the Joint Commissioner of Kolkata Police, Ms Damayanti Sen. Admirable! And justice eventually was meted out, with all the convicts given life imprisonment.

And there comes the cause for question. While there had been innumerable people who had been with her, if not physically, in her strife for true justice, there were also some others who deduced that for a woman who lurks in night clubs in the dark of the night, inebriated and intoxicated, what happened was no surprise or shock. And we still say that gender inequality exists no more. No one raises a brow when a man wanders in night clubs, or gets drunk, or befriends strange women. It is normal. It is common. He is a man. But even in this day and age, a woman frequenting a night club and indulging in alcohol is deemed "immoral"... "licentious." We are in the twenty-first century; we call ourselves civilized, modern, liberal. We claim to believe in equality of the sexes, and non-existence of gender-discrimination. Yet, we are still steeped in the thought processes of primitive days. Ironical!

Gender bias goes back a long way. It is a legacy that has been passed down from one generation of males to the next. It is not possible, without any kind of controversy or contradictions, to single out its root cause or origin. It might go back to the days of Adam and Eve, when Eve was repeatedly warned by Adam to stay away from the Forbidden Fruit of Knowledge of Good and Evil. I mean, what right did Adam have to dictate Eve on what she should and should not do? Unless of course he felt protective of her, considering that she is deemed to have been born out of his rib. And the feeling of protectiveness always develops for someone deemed weaker, needing protection. Or it might go back to the Stone Age, when men, physically stronger, went out with their arms and weapons to hunt for food while the womenfolk stayed behind in the caves to look after the off-springs and the livestock.

The role and status of women in the ancient world varied from place to place. Whether it was as an equal partner and loved one, like in Egypt and many Celtic societies, or as a slave in everything but name, like in Athens and, to a lesser extent, in Rome, the role of women was dependent on the culture of the place.

Women in Egypt throughout that country's history have always been treated better than women in Greece and Rome. In Egypt marriage was not simply a man's civic duty, it was a about love, it is important to note that in Egypt marriage was never forced on women. In the Egyptian household, women reigned supreme. By contrast the role of women in most of Greece was very, very different. In Athens it was believed that a woman was endowed with strong emotions and passions and weak minds. And thus, every woman was assigned a kyrios (guardian) who had the ultimate say in every aspect of that woman's life. Marriage in Athens was treated as a social and civic duty that men had to fulfill, to ameliorate their financial status, and beget heirs to continue the family line. Women had to confine themselves within the four walls of their homes, and the only occasion they could grace was any religious ceremony, but that too in the company of their kyrios.

In Sparta, women lived a little differently from the rest of Greece. Although Spartan men did believe that the women were only the means to produce more strong Spartan men, as is evident by the practice of an unmarried man asking a married man's permission to borrow his wife to beget male heirs, they still enjoyed more legal rights in other areas than the rest of Greece. In Sparta women had the right to own property and when a noble died the estate was divided equally amongst his sons and daughters. Spartan women enjoyed the privilege of going out in public and even compete in athletic events. Women reigned supreme in the Spartan household and men had to obey their wives the few times they happened to be home. The rest of Greece, in fact, was very sure that the fall of the Spartans would be brought about by their giving their women too many rights.

Women were not regarded with any more respect in Rome than in most of Greece. In the days of the Roman Republic, the general belief was that the most efficient way to run a family was to hand over all control over everything on one man. These men were called paterfamilias. Women in Rome were just another one of the personal properties held by the paterfamilias; when a woman married, it was seen as transferring control from her paterfamilias to the groom and his paterfamilias. This remained the unwritten law until the time of the Second Punic War. Thenceforth, women gained more and more power, until Octavian (Augustus) was made Emperor, because the paterfamilias who controlled the family was often serving in the army. By the time of the 
Civil War between Octavian and Brutus, women could marry in a ceremony that did not place her under the authority of her husband. However, after Octavian ascended the throne as Emperor, he believed that he had to somehow reverse the current state of morality in the Empire. Thereafter, he established a new code of family values, according to which restrictions were placed on the attendance of women at public occasions. A father could kill his daughter and her lover if he caught them in the act of adultery. In his own home, a husband could kill his wife and her lover if he caught them in the act of adultery. A husband had to divorce his wife within sixty days if it was proved that she had indulged in an act of adultery. It was mandatory for men under sixty and women under fifty to marry. Failure to do so would mean they could not inherit.

Women with three or more children had to wear a special garment and were freed from the authority of their husbands. As time passed, these laws became steadily more and more unpopular, though it lasted till the era of Constantine, who instituted Christian moral reforms.

The scenario was, however, different in the lands of the Celts. The women were believed equal to men in every respect. There was really nothing they were not allowed to do in Celtic society. It is well known that Celtic women were very fierce and were regarded as warriors, to be feared by all men. A typical example was when a group of women scared a Roman army under Caius Paulinus who was advancing on a Druidic stronghold in modern Wales. There was really no problem with women holding supreme power in a Celtic kingdom; it was a common practice. The most famous of these were Boudicca of the Iceni, Cartimandua of the Brigantes, and Medb of Connaught. Women enjoyed a number of privileges in public life. There is evidence of their being mediators in a variety of disputes, civilian and military. In marriage, Celtic women, as with Egyptian women, were equal partners with their husbands. Women had a number of rights while married, they were even allowed to own property independent of their husbands, and like in Egypt and Sparta, the women reigned in the house.

In India, the evolution of and metamorphosis in the status of women has been a continuous process of ups and downs throughout history. Considering the vast body of empirical research available on the topic, two approaches seem valid: one is classical text view; and the other, empirical view. Throughout classical literature on the status of women there is an almost consistent opinion among great scholars that during the age of the Vedas $(2500-1500 \mathrm{BC})$ a woman's status was equivalent to that of a man.

Though it is difficult to specify chronologically when exactly the deterioration in women's status started, one can state that gradual changes appeared during the age of the Brahamanas, and by the age of the Sutras and the Epics and the age of the later Srutis, the status had deteriorated considerably.

Thus, we can see that although the status of women varied from one place, society, and culture to another, barring a few scant exceptions it was equally miserable everywhere. Sivakumar Marimuthu, $\mathrm{PhD}$ Scholar in Economics, Chikkaiah Naicker College, Erode, Tamil Nadu, has identified the key reasons why women have been discriminated against: educational backwardness, caste, religious beliefs, culture, in the name of family history, customs and beliefs, races, low income, unemployment, society, family situation, and attitudes.

"Sex class is so deep so as to be invisible. Or it may appear as a superficial inequality, one that can be solved by merely a few reforms...." (Firestone 63). So many women wish this were true. A few minor modifications in the social system and voila! Men and women are equal. Unfortunately, it is not that easy. Gender discrimination has multiple manifestations. Some distinct, some not.... Like the instance stated right at the beginning. Truth is that, from womb, to death, women face atrocities in myriad forms: female foeticide; abortion; killing a female new born baby; lack of provision for sufficient or nutritious food; denial of education; lack of provision for required health care in ill health; early marriage; eve teasing, rape, and sexual harassment; dowry; divorce, and destitution, even for the slightest of reasons. From time immemorial, women have been suppressed, tortured, intimidated, thanks to patriarchy and a perpetually male-dominated society. But as old is the history of gender bias, so old are the voices raised against it: "feminism," the voice against female subjugation.

The term "feminism" may belong to contemporary times, but its roots go much further than that. Feminism is deemed to be the movement to put an end to women's oppression. One significant way to understand 'woman' in this claim is to accept it as being a sex term: 'woman' refers to the human female and being a human female is dependent on a number of biological and anatomical characteristics. However, according to many feminists, 'woman' is not a sex term; rather it is associated with gender. While most people consider sex and gender coextensive (women are human females and men, human males), through history feminists have distinguished between the two. According to them, 'sex' denotes human females and males depending on biological features (chromosomes, sex organs, hormones, and other physical features); 'gender' denotes women and men depending on social factors (social role, position, behaviour or identity). This distinction was fuelled by the motivation to counter biological determinism or the conviction that biology is destiny, as behavioural and psychological differences are triggered by social, rather than biological causes. As 
the famous claim by Simone de Beauvoir professes, that one is not naturally born a woman, but rather becomes a woman. "Social discrimination produces in women moral and intellectual effects so profound that they appear to be caused by nature" (Beauvoir 18).

In startling contrast to this claim, is the biological determinist view of Geddes and Thompson, who, in 1989, argued that social, psychological and behavioural features were caused due to metabolic state. According to them, women supposedly conserve energy, (since they are 'anabolic') and hence, are passive, orthodox, slow, sound and uninterested in politics. Men, on the other hand, prefer to spend all their energy (since they are 'katabolic') and are, therefore, eager, energetic, vigorous, laborious, passionate, restless, variable, and hence, interested in politics and society matters. The difference in the metabolic states explained their behavioural distinction and also suggested and justified what social and political set up should be like. According to Geddes and Thompson, "what was decided among the prehistoric Protozoa cannot be annulled by an Act of Parliament" (Moi 18).

What these eminent thinkers refused to add was that neither did the "prehistoric Protozoa" decide that women be deemed the weaker sex. And many women across the globe have vouched for this since time immemorial. And many women across the globe have raised their voices in protest against this discrimination since time immemorial. For, although the term "feminism" may belong to modern times, its roots can be traced much further back.

Independent women, not believing in gender inequality, have always existed in society. As far back as the sixth century BC, in Greece, Sappho composed lesbian poetry and ran a school for girls. Sappho is hailed as the greatest female lyrical poet of the classical Lyric age of Greece. Her poetry about female love has also rendered her stance as one of the earliest feminist writers, long before such a concept of feminism existed. She is also known for the training she imparted to many young women in their social and marital responsibilities of the time. However, whether she lived her life as naturally destined or killed herself for love of Phaon, is an enigmatic mystery. What is not a mystery is that her poetry has endured the ravages of time. Plato called her the tenth muse, Horace emulated her, and Ezra Pound was inspired by her. Sappho's work ensured for her a prominent place in a male-dominated culture and the legacy that she handed down to us has inspired women across the world.

Christine de Pizan has been claimed to be the first European woman to take up writing as a profession, when she was unexpectedly left to support herself and her family on her own. Uncommonly well-educated for a woman belonging to her times, she wrote extensively about love and chivalry, mythology and legends, peace, history and the misogyny of male authors, who, she sincerely believed, belittled women in their compositions. During the Renaissance, Christine de Pizan diverted from the traditional roles assigned to women in several ways during a time when women were given no legal rights and were considered a man's personal property.

In the seventeenth century, Aphra Behn was a poet, playwright, novelist, translator, and spy. Born in 1640, she was one of the first English women to become a professional writer, who successfully compelled the men who dominated the jealous literary world of Restoration England in the seventeenth century, to pay respect to her as an equal. She was a feminist who vociferously defended the right of women to an education, and the right to marry who they pleased or not at all. She was a pioneer in matters of sexuality as well, one who professed that men and women should love freely and as equals. She was also a political activist who argued for the Royalist point of view and became a spy for Charles II against the Dutch.

Debatable issues of rights and gender equality have always prevailed in our society, but equality during the French Revolution was a gripping concept to put into effect. Although women played a major role in the French Revolution, a period calling for liberty and equality, their involvement always proved controversial, and from the viewpoint of the majority, women were overbearing and did not deserve citizenship. However, contrary to popular belief, women were not troublemaking revolutionaries and they were willing to go to any length to establish their vast mental capacity.

The eighteenth century gave birth to liberal feminist activists who spread their words about and against the harsh treatment of women. One of the first works to rebel against the overwhelming unkind attitude towards women, was Olympe de Gouges' Declaration of the Rights of Women, in which de Gouges stated, "Woman is born free and remains equal to man in rights ... The aim of every political association is the preservation of the natural ... rights of man and woman." (Perry 360) Unfortunately unrestricted political activism was to cost her her life, and in 1793 she was persecuted at the guillotine. Parisian women formed political clubs and associations to discuss and campaign issues affecting them. However, the male leaders of the Revolution were not supportive of their attempts, rather they were openly hostile, and in 1793 they outlawed all women's clubs, announcing that a woman's rightful place is at home, not out of it. This hostility continued through the $19^{\text {th }}$ century, and during the reign of Napoleon, the management of family finances and funds was handed over to the man of the family. Only in 1909 did French women gain control over their own earnings, and in 1944, they got the right to vote. 
In North America, women actively participated in the freedom struggle and exercised their power as consumers by boycotting British goods. During this time, Britain too, witnessed a spurt of radical and reactionary writing about women. One of the most prominent ones who rose to fame through feminist writing was Mary Wollstonecraft, a British journalist, keeping close vigilance over the events in France. She became a journalist to support her family, but in 1787, she moved to London, to earn her living through writing, and joined a radical circle of intellectuals. A year after Thomas Paine wrote The Rights of Man (1791), Mary Wollstonecraft gave voice to her views in favour of women's liberation in A Vindication of the Rights of Women. However, as expected from her times, she was dismissed by the male conservative press as "a strumpet".

The eighteenth century, again, was the turning point for black women slaves in America, as Protestant Evangelism combined with the anti-slavery movement. Soon black women realized that freedom from whites was not sufficient anymore; freedom from men too had to be attained. However, being a black feminist was tough, as Sojourner Truth, adopted as a powerful symbol for both feminists and African-Americans through the years, witnessed when white racist women tried to stop her speaking before the Second Annual Convention of Women's Rights in Akron Ohio in 1852. The early 1900s represented Truth primarily as a feminist, but by the 1910 s and onwards, she was heralded as a symbol for equal rights for African Americans.

In the course of the Industrial Revolution, single women were leaving home to earn their livelihood, mostly at shockingly low wages in terrible factory conditions. At the same time, the idea of female education was proliferating and women hailing from the middle classes were demanding more job options. Women began playing an active role in the industries on both sides of the Atlantic. During the Weavers' Strike in Britain in 1808, The Times publicized striking women handloom weavers, who constituted a sizeable percentage of the handloom weavers, as "more turbulent and mischievous than the men." The first strike to be organized and led entirely by women was in 1828 in the Cocheco Manufacturing Co in Dover, New Hampshire, a firm organized on the Waltham-Lowell plan. Restrictive regulations were introduced into both the boarding houses and the mill, including no talking and visiting in the mill. In response, 300 to 400 women "turned out" and marched with banners about town. The protest was brief but unsuccessful. Similar protests took place in Lowell, Massachusetts, in 1834 and 1836. In Britain, in the 1850s, Barbara Leigh Smith Bodichon was the most unconventional and influential leader of the Victorian women's movement. Amazingly talented, vital, and original, she was a feminist, law-reformer, painter, journalist, close friend of George Eliot, and a cousin of Florence Nightingale. As a painter, she is now recognized as a vital figure among Pre-Raphaelite women artists. As a feminist, she was the leader of four great campaigns - for married women's legal status, for women's right to work, to vote, and to be educated. Pamela Hirsch has written a biography that is as lively and powerful as its subject, resurrecting this half-forgotten figure and placing her squarely in the context of women's struggle for equality. In 1854, Barbara wrote her first nation-wide publication, A Brief Summary, in Plain Language, of the Most Important Laws concerning Women, which documented for the first time the legal disabilities and restrictions under which women lived. The same year, she assimilated for the first time, a congregation of women, who called themselves feminists and campaigned to change laws. In East London, a strike by women in a match factory contributed to the rise of the British Trade Union Movement.

In nineteenth century Asian and African countries, women were slowly fighting against traditional, cultural, and colonial oppression. During the Taiping Rebellion in 1850-1864, Chinese women feminists posed a challenge to the very nature of the Chinese imperial system. This rebellion endeavoured to overcome the Qing Dynasty, and impose not only a new government but also a new culture. One facet of this new culture was a differing view of women's roles. For over two millennia, Chinese women suffered terrible atrocities under the subjugation of men. They were held inferior to their fathers, husbands, and even sons. Women were confined in inner chambers and expected only to look after matters of the household. A woman's attractiveness was based upon the size of a woman's feet. Smaller the size of the feet, more attractive was she taken to be. To ensure smallness, a woman's feet would be agonizingly and torturously bound when she was still a young girl. Under the Taiping code, these social customs underwent a transformation. Feet were to be unbound and women to be brought out of the inner chambers. Giving into the demands of women, the Chinese language was simplified, and equality between men and women was decreed. All property was to be held in common, and equal distribution of the land according to a primitive form of communism was planned. British colonialists formed alliances with groups which were the most conservative and known for their oppression of women. As a logical consequence, British colonialists in India were in staunch encouragement of arranged marriages, dowries, and education only of men. But in the early 1900s, women had significantly contributed to Indian freedom struggle to attain independence and were almost at par with their male counterparts. In 1905, women actively participated in the Swadeshi Movement to boycott foreign goods and in 1917, Women's Indian Association was established by a group of progressive women with a common goal of helping distressed women and children, and with links to the British Movement for women's suffrage. Around the same time, in 1923, the idea of the first Egyptian Women's Federation emerged, which sought political and socio-economic rights for women. It 
managed to create a political entity that had a major impact on political life as well in the face of the British occupation. Women, within only a few years, were able to shift from face covering (the wife of the late political leader Saad Zaghloul took off the face cover in 1919) which inspired other women to follow. The Egyptian Women's Federation was formed in protest of African women being banned from entering the cities, and being denied traditional access to land. In 1924, a major achievement was witnessed by the Egyptian Women's Federation, with the age of marriage for girls being raised to 16.

Women's suffrage was an issue creating ripples of antagonism amongst women everywhere, with women's call for the vote reverberating around the world. This call was first answered in Aotearoa, New Zealand in 1893. In a staunch rebellious voice calling for women's right to vote, Emmaline Pankhurst, supported by her two daughters, Sylvia and Christabel, organized mass meetings in Britain, that drew people in multitudes, with resolute, infuriated militants chaining themselves to railings and causing civil disturbance. In 1908, the Pankhursts were arrested and imprisoned, which led them to go on a hunger-strike, and then being force-fed, giving rise to public furore. In spite of all the rebellion and protests, it was only in 1918 that women (over the age of 30) got to vote. In the United States, it was 1920 when women were allowed to vote. In India, Provincial Assemblies were allowed to enfranchise women in 1919. In 1913, the Indian National Congress Party pledged to always work for sexual, caste and religious equality in independence. Ecuador was the first Latin American nation to give women the vote, in 1929, followed by Brazil, Argentina, Chile, and Cuba in the 1930s.

Feminist denunciations of male patriarchy share a common origin: the Marxist creed. In the 1840s, Marx pointed out: Working men were oppressed by capitalist economies, and women were doubly victimized, as they, like men, were not only held captive by the structure that is capitalism, but were also subjected to patriarchal oppression. This is how Karl Marx and Frederick Engels explained it in their 1848 Communist Manifesto: "What is the present family based on? On capitalism, the acquisition of private property...The bourgeois sees in his wife nothing but an instrument of production." (Marks and Engels 27 ). In 1884, Engels elaborated on the theme of patriarchal oppression in his work The Origin of the Family : "The overthrow of mother right was the world historical defeat of the female sex. The man took command in the home also; the woman was degraded and reduced to servitude; she became the slave of his lust and a mere instrument for the production of children." (Martens 80).

Marx and Engels viewed women's liberation as part of the socialist revolution. Clara Zetkin, born as Clara Eissner in the small village of Wiederau in Saxony, Germany, strove for the economic liberation of women workers, and women in general. As a consequence, the right to the same wages for the same work was linked to union organisation, the representation of interests, and state child care. At the same time, women were to receive the same political rights. She supported the women's voting right campaign later than the civil women's movement, but with vehemence and assertiveness, and spoke in favour of this demand being taken up in the German Social Democrat programme. The International Day of Women, first celebrated in 1911, was staged thanks to her suggestion. At the same time, Zetkin also spoke out for amelioration in the role of women in the family. Until that time the life of the woman had existed in subordination to the family. In contrast, marriage was meant to be a union of couples with equal rights, who enrich one another reciprocally. Husband and wife are both responsible for raising the children, which should take place free of gender-specific stereotypes.

Zetkin approved of divorce, "free love," and abortion as personal decisions and stood up against double morals. In Germany, Rosa Luxemburg, along with Karl Liebknecht, was to play a significant role in the months that immediately followed the Armistice in November 1918. Rosa Luxemburg was one of the key leaders of the Spartacist movement, and vehemently against self-determination as she believed that a newly created state was weak and at a disadvantage to the people there as the "bourgeoisie" would use this national weakness to their advantage to strengthen their hold over the workers. Her view was opposed by many and as a result Luxemburg formed the Polish Social Democratic Party. In 1898, Luxemburg left Zurich for Berlin where she joined the German Social Democratic Labour Party. Any significant list of radical thinkers, rebels against existing social orders, must include Alexandra Kollontai, the gifted Russian orator, writer, and passionate forerunner of socialist feminism. Kollontai saw socialist revolution and women's liberation as inseparable, recognizing that in order for women to participate equally in society, our second-class standing as workers must be eliminated and our unpaid domestic labour transformed into communal responsibility. The year 1918 saw the first Women's Conference being held at Moscow, and in the 1920s, the Soviet Government, under Lenin, promoted equal rights. Communist Russia, established by the Bolsheviks through the Russian Revolution of 1917, was the most radical government in Europe at the time. Its utopian convictions on how the nation should be administered and what values were more important over others were radically divergent from the traditional beliefs held by most nations in Europe. One part of these radical visions the Communists had concerned women and their equal status in society. They proposed a whole new idea of family and the roles of women and men.

Lenin asserted that the success of a revolution depends on the participation of women. Lenin genuinely valued the support of women and aggressively fought to achieve their true emancipation and equality with men. 
In spite of his ideologies failing to penetrate deep into all of society, he did succeed in pursuing several policies within his party and the state, to help bring about marked changes in the living conditions and positions of women in Communist society. Marriage, divorce, and contraception were all made simple. However, in the 1930s and 1940s, in Russia during Stalin and World War II, the Communist government's original goals to achieve a completely utopian state were looked down upon and abused, and women were frequently encouraged to embody new kinds of values and hold different beliefs. Stalin's bureaucracy, as opposed to Lenin, believed that the traditional family, as the basic unit of society, was beneficial to enforce its policies. Therefore, it formulated new laws to bring that new structure back. It placed new restrictions on women's independence. First, divorce became more difficult to obtain, because marital stability was a vital requirement in the newly bureaucratized Soviet Union. Only a fortunate and obviously affluent few could actually afford to get a divorce because the government required payments (often a huge amount) for divorce. Also, abortions were abolished except for cases in which the woman's health was at risk. The government coercively instructed women that they had to imbibe in themselves to "enjoy motherhood.". This restriction on abortion had its roots mainly in the paucity of labour after World War I and the civil war. Abortion was legally discouraged to increase the population. Women who gave birth to more than nine children were awarded medals. Finally, the number of communal services, such as nurseries and laundries that had been established to help women focus on their work, slowly declined, causing women to be inevitably confined within their homes. In the Chinese revolution of 1949, women were endowed with greater rights and freedoms. To demonstrate the success of communism, Mao made the public declaration that women and men are equal. He put both sexes under compulsion to wear gender neutral clothing and demanded equal labour in the factories and fields. Women were relieved of the burden of child care with the implementation of communal living. The state now officially recognized women as equal members of society. Some visible signs of this were legislation that outlawed oppressive and binding marital practices and made divorce legal. In Russia too, women were encouraged to work outside their homes, along with the household chores. However, in the West, feminism was still not strongly prevalent, owing to the radicals being preoccupied with battling unemployment, fascism, and McCarthyism.

During the American Revolution, American women, just as their European counterparts, were definitely an oppressed group. They were generally not given education and usually had no financial resources of their own. If they did earn an income, they rarely had any control over it. Married women were legally dominated by their husbands and completely dependent upon them. Middle- and upper-class women had the pleasure of material comfort, but were confined and restricted everywhere by rigid social norms and the sexual double standard. Besides, women had no political rights, could not work in office, and were not allowed to vote. Many women accepted their unequal status without question, but there were also others who took an active interest in political life and who became increasingly disgruntled with their continued exclusion. The new ideas of liberty, equality, and democracy that were being discussed by men spread amongst intelligent women, and when the American colonies prepared for their secession from the English Crown, female hopes for sexual equality were naturally high. In 1920, the country adopted the Nineteenth Amendment to the Constitution granting the right to vote to women. A struggle of over seventy years had finally been won. During the 1960s, feminism raised its head again in the US, manifesting itself through a radical culture that incorporated, among others, the Civil Rights and sexual liberation. In 1953 Simone de Beauvoir's The Second Sex had appeared in English translation, with stupendous success, an influential book that analysed the history and implications of female subjection in Western culture, followed by Betty Friedan publishing The Feminine Mystique, in 1983, openly criticizing the prevailing stereotypical role of the American housewife and mother. Also in 1963 a Presidential Commission issued a report, American Women, which recommended a number of moderate reforms to improve their status. In response to these and other developments, the National Organization for Women (NOW) was founded in 1966 and soon became the largest and most widely renowned of various new women's organizations. NOW almost immediately took up the fight for an Equal Rights Amendment and demanded several other drastic reforms, such as the right to abortion. In the meantime, these demands found much wider support than previously, because many middle-class women had become radicalized through the renewed black civil rights struggle, voter registration drives in the South, and the peace movement against the American war in Southeast Asia. Sexual and reproductive liberation could be discussed more openly, as the whole country had become more sensitive to issues of fairness and individual freedom. In the early 1970s the abortion issue was suddenly settled by the U.S. Supreme Court in the feminists' favour. Moreover, Congress finally passed an Equal Rights Amendment stating "Equality of rights under the law shall not be denied or abridged by the United States or by any State on account of sex.". Feminist groups also sought reforms in childcare, health, welfare, and education. The Second Wave of feminism emerged in West Europe, Australasia, and Japan in the 1960s and 1970s. In the case of the UK, second wave feminism began in small local all-female discussion groups aimed at raising women's consciousness of the facts that they were all experiencing similar individual private problems which nevertheless were caused by the patriarchal social structures which oppressed and exploited women in society generally. The clarion call to change that galvanized a generation, when Germaine Greer's The Female 
Eunuch was first published, it created a shock wave of recognition in women, one that could be felt around the world. It went on to become an international bestseller, translated into more than twelve languages, and a landmark in the history of the women's movement emphasizing that sexual liberation is the key to women's liberation, Greer looks at the inherent and unalterable biological differences between men and women as well as at the profound psychological differences that result from social conditioning. The year 1975 was termed 'International Women's Year (IWY)' by the United Nations, and proceeding that year, March 8 has been celebrated across the world as International Women's Day. The same year, United Nations Decade for Women, from 1976-1985, was also established. Revolutionary movements in Zimbabwe, Angola, Mozambique, and Nicaragua incorporated into their fabrics the struggle for equality of the sexes. And gradually, the awareness of equality of the sexes started spreading far and wide.

From $\mathrm{BC}$ to $\mathrm{AD}$, the strife for equality, for emancipation continues. Much has been said, much is still said about feminists and feminism. Are women at par with men? Are they not? Speculations, discussions, deductions continue rampant. But there is still a long way to go before society can claim itself unbiased towards the genders. This work proceeds to reflect on a very valuable truth: where we have been, where we are, and a shockingly relevant treatise on what still remains to be achieved.

\section{Works Cited}

[1]. Bhaskar A Shukla. Women On Women: A Feminist Study. Saroop \& Sons, 2006

[2]. Perry, Marvin. Western Civilisation, Brief Voume II, $10^{\text {th }}$ Edition. Cengage Learning

[3]. Marks, Karl and Engels F. The Communist Manifesto. New York. 1948

[4]. Martens, Lorna. The Promised Land?: Feminist Writing in the German Democratic Republic. SUNY Press, 2001 